\title{
THE COLLECTIVE SECURITY TREATY ORGANIZATION (CSTO) IN THE FOREIGN POLICY OF THE RUSSIAN FEDERATION
}

\begin{abstract}
Paradoxically, the process of reintegration of post-Soviet area has been taking place since the collapse of the USSR. The motive of Russia's efforts to reintegrate this region is the historically driven belief in Moscow's role as a leader in this part of the world, and the strong cultural, economic and political ties that connect it with the former Soviet republics. The former republics of the USSR also feel strong ties with Russia. In addition, the ruling elites feared the future after the collapse of the USSR, especially at the beginning of the formation of their independent statehood, which determined the decision to establish strong cooperation with Russia. Today, after nearly thirty years, the reintegration process still continues although its intensity and the number of countries involved have changed. One of its areas is the sphere of security, which is confirmed by the activity of the Collective Security Treaty Organization, where Russia plays a key role. In this context, the author attempted to answer the question: What role does the CSTO play in Russia's foreign policy?
\end{abstract}

\section{Key words}

reintegration, post-Soviet area, CSTO, foreign policy, Russia 


\section{Introduction}

From the first days of the Russian Federation, its authorities have been convinced that Moscow's leadership in the post-Soviet area is unquestionable and undeniable. Since new independent states emerged in the place of the former Soviet republics, Russian leaders have done a lot to influence these theoretically sovereign countries. They treat this region as a priority in terms of their vital geopolitical interests. This is reflected in Russian foreign policy - in the organized and outward-directed effort, subordinated to the achievement of Russia's interests, which is expressed in shaping its external environment (creating relations and favourable situations; preventing and removing adverse conditions) (Kuźniar, 2000, p. 122). This is evident in the efforts to create structures for political, economic and security integration within the post-Soviet region. Moscow is thus seeking, through a wide range of instruments, to prevent these states from falling under the influence of any other entity - the US, EU, NATO or China. Russia realizes that the loss of influence in the post-Soviet area will ultimately ruin chances of regaining the status of a superpower. In this respect, the goals of the foreign policy of the Russian Federation do not differ fundamentally from the goals of any other power (Legucka, 2016).

The purpose of this article is to determine the role and place of the Collective Security Treaty Organization (CSTO) in the foreign policy of the Russian Federation. The main research problem was included in the question: What role does the CSTO play in Russia's foreign policy? The author adopted the assumption that, in practice, the CSTO contributes to the improvement of the Russian Federation's security, increases its strength, and raises Russia's international prestige. In the research process, the author referred to the positivist and postpositivist approach, because the so-called mainstream theories, including realism (widely present in Russian foreign policy) belong to the positivist theories (Czaputowicz, 2008, pp. 50, 53). The positivist approach assumes that the research process should use facts and empirically perceived phenomena, which are the foundation of the research conducted by the author. 


\section{The reintegration of post-Soviet area}

The process of reintegration of the post-Soviet area began already during the collapse of the Union of Soviet Socialist Republics (USSR), which from the perspective of the newly emerging, sovereign states could seem quite surprising. However, it turned out that in these weak, emerging countries the fear of the future was stronger than the joy of regaining independence. Fear related to the need to find their place in the new international reality had stimulated the construction of integration structures linking the Russian Federation and former Soviet republics. And so, on December 8, 1991, the presidents of Russia and Ukraine and the chairman of the Supreme Council of Belarus decided to create the Commonwealth of Independent States (CIS). Thus, the process of reintegration of the post-Soviet area began, which, according to the Russians, was an opportunity to maintain Russia's influence. In the newly created countries it also eliminated fear and a sense of loneliness in the international space. The main factors motivating the Soviet states to join the Community were economic factors (strong links with the Russian economy), issues related to the division of the armed forces and armaments, ensuring effective implementation of security policy, and concerns about the expansion of Islamic fundamentalism, especially in the Caucasus and Central Asia.

The agreement, under which the CIS was established, defined the following areas of cooperation: coordinating activities in the field of foreign policy, shaping and development of the common economic space, European and Eurasian market, customs policy, development of transport and communication systems, environmental protection, migration policy, and combating organized crime (Baluk, 2008, p. 13). On December 21, 1991, eight more republics joined the Community. Georgia was the last to become a part of this entity. As a result, the CIS comprised 12 post-Soviet countries.

The organization, founded on the basis of the Treaty on the Commonwealth of Independent States, was not the only organizational structure. From that moment, the states formerly belonging to the USSR sought various forms of integration. In this area, bringing together (to a different degree) former Soviet republics, over the years (since the fall of the USSR), the following institutions operated at some point or are still active: the Eurasian Economic Community (EAEC); the Organization for Democracy and Economic Development (referred to as GUAM, an acronym made up from the first letters of the member states - Azerbaijan, Georgia, Moldova and Ukraine); the Collective Security Treaty Organization 
(CSTO; Organizacija Dogovora o Kollektivnoj Bezopasnosti, ODKB); the Central Asian Union (CAU); the Common Economic Space (CES); and the Union State of Russia and Belarus. Cooperation and membership in the Shanghai Cooperation Organization (SCO; Shankhayskaya organizatsiya sotrudnichestva) and in the Organization for Security and Cooperation in Europe (OSCE; Organizatsiya po bezopasnosti i sotrudnichestvu v Yevrope) goes beyond the CIS area. Recently, successful efforts have been made to establish the Eurasian Economic Union, an integration structure modelled on the European Union.

As already mentioned, the sphere of security was to be one of the areas of cooperation within the CIS. Cooperation between intelligence and other security structures is intensively developing in the Commonwealth of Independent States. In the 2009 National Security Strategy of the Russian Federation and the Foreign Policy Concept of February 2013, cooperation within the CIS became a priority. It is noteworthy that the former director of the Foreign Intelligence Service Sergei Lebedev holds the post of the CIS Executive Secretary. Such a position being held by an intelligence officer of such rank demonstrates Russia's full control over all issues and full knowledge of Community affairs. This is clearly demonstrated by the statement in the Russian media. According to Lebedev,

in the post-Soviet space, close coordination of the CIS countries' special services is underway. I am a witness to this. Their representatives regularly meet, including at high level. There is the Council of Heads of Security Agencies and Intelligence Services of the CIS countries chaired by FSB Director Bortnikov. The council meets regularly. I am also invited to its meetings. This cooperation is quite active, it brings results. The CIS Council of Ministers of Internal Affairs, headed by Russian interior minister Rashid Nurgaliyev, works effectively. I have participated in many meetings of this council, so I am constantly familiar with the issues raised by the interior ministers. These contacts and cooperation significantly contribute to strengthening security and legal order in friendly countries [...] (Makarychev, 2011).

This cooperation has a practical dimension. "The partners support each other morally, politically and materially [...] as part of cooperation between special services, joint ventures of an operational nature and a wide exchange of special information are carried out" (Makarychev, 2011). Intelligence and other services meet annually as part of the summits of the heads of security authorities and CIS intelligence services', during which they agree on priorities for intelligence activities and operations (Vneshnyaya Polityka, 2009).

The CIS structures, to which Russia gives political direction, including the aforementioned intelligence cooperation (See: Lefebvre \& McDermott, 2008, 
pp. 251-301) are used to achieve the aims of Russian foreign policy, which focuses on preventing US' presence in any form and neutralizing its influence on the fight against terrorism and on energy policy in the former Soviet republics, mainly in Asia. Plans to station American troops in Central Asian countries aroused nervous reactions, despite the fact that their only purpose was to provide operational and logistical support for the troops in Iraq and Afghanistan.

\section{Objectives and tasks of the CSTO}

On May 15, 1992, on the initiative of the Russian Federation, States-Signatories of the Commonwealth of Independent States signed in Tashkent a collective security treaty, commonly known as the Tashkent Treaty. As Walenty Baluk noted: "the idea of collective security formulated in the treaty has evolved over time, eventually taking the form of a defence alliance, which is not about security at all, but only one of its types - military security" (Malak, 2008, pp. 23-40).

The material expression of the mentioned evolution was the transformation of the Tashkent Treaty in May 2002 into an international regional organization the Collective Security Treaty Organization. In fact, among all these integration initiatives, the CSTO is a priority for Russia. The mission of the Organization, which brings together Armenia, Belarus, Kazakhstan, Kyrgyzstan and Tajikistan, is military cooperation and defence of the CIS area. In Russian military doctrine of February 2010, priority was given to military-political cooperation with Belarus, the CSTO and the CIS ("Voyennaya Doktrina Rossiyskoy Federatsii”, 2010, paragraphs $19 \mathrm{~d}$ and $51 \mathrm{a}, \mathrm{b}, \mathrm{w}, \mathrm{g}$ ).

The main goals set for the Organization are promoting peace, strengthening international and regional security and stability, ensuring collective defence of independence, territorial integrity and sovereignty of member states (Mowchan, 2009 , p. 1). In this context, the most important is Art. 4 of the CSTO Charter, modeled after Art. 5 of the Washington Treaty, which stipulates that in the event of an armed attack against one or more Member States, the other states will provide the necessary assistance, including military assistance, as well as support by their means, based on the right to collective defence, in accordance with Art. 51 of the Charter of the United Nations.

Not only is the content of Art. 4 similar to the provisions of the abovementioned Art. 5, but also the CSTO's most important bodies reflect the structure of the North Atlantic Alliance. These include: the Collective Security Council (in NATO - the North Atlantic Council), the Permanent Council of the CSTO 
(in NATO - the North Atlantic Council in the format of permanent representatives - ambassadors); the Council of Defence Ministers (in NATO - the North Atlantic Council in the formula of defence ministers and the Defence Planning Committee); the CSTO Committee of Secretaries of Security Council (in NATO - Political Committee and Policy Coordination Group); CSTO Joint Staff (in NATO - Military Committee, International Military Staff); and Collective Rapid Reaction Forces, Collective Operational Reaction Forces and Collective Peacekeeping Forces (in NATO - strategic commands - Allied Command Operations and Allied Command Transformation (see Kaszuba, 2017, p. 129).

Basically, the intention of the CSTO member states is to create a strong alliance capable of resisting external threats. From Moscow's perspective, it is an invaluable forum where Russia can strengthen its influence in the postSoviet area; in fact it is one of the numerous instruments of Russian foreign and security policy. This is confirmed by the provisions contained in the Security Strategy of the Russian Federation, according to which the Collective Security Treaty Organization is the main instrument capable of opposing regional challenges and threats of a military-political and military-strategic nature (Strategiya natsional'noy bezopasnosti Rossiyskoy Federatsii, 2016, par 13).

After the Russo-Georgian War, Russia proposed that the other members of the Organization should strengthen its military capabilities. In response, the member states during the CSTO summit in Moscow in February 2009 decided to create a Collective Rapid Reaction Force of 16,000 soldiers. Russia assigned to this force around 8,000 soldiers from the 98th Guards Airborne Division, which participated in the Russo-Georgian War and the 31st Guards Air Assault Brigade, which participated in the Second Chechen War in 1999-2000. Kazakhstan assigned 4,000 soldiers from the elite 37th Guards Air Assault Brigade. The remaining 4,000 soldiers were provided by Belarus, Armenia, Kyrgyzstan and Tajikistan.

These forces deal with the following tasks: combating terrorist and extremist threats, combating drug trafficking, repelling possible military aggression, providing support in the event of natural and technical disasters.

At the same time, the Kremlin wanted to create a grouping of forces in Central Asia to secure it against external aggression. The strengthening of military capabilities was inspired by Russia due to the further expansion of NATO to the east, which in Moscow's opinion was confirmed by the accession of Albania and Croatia to the Alliance in 2009 as well as by Georgian and Ukrainian efforts towards this goal. Fears regarding the deployment of elements of the US missile defence system in the countries of the former Eastern Bloc were also of great 
importance. To sum up, the expansion of the CSTO's military potential aimed, according to the Russians, to offset the potential of the North Atlantic Alliance.

Another argument was the deepening instability of Afghanistan and Pakistan as a result of Islamic extremist activity and the accompanying fear that it could spread throughout Central Asia and Russia itself. Such developments could pose a serious threat to the vital interests of the CSTO member states. Transnational threats in the post-Soviet area largely determine the organization's work agenda. These include Islamic terrorism and its impact on the security of the member states, which may be perceived as a transnational, external or internal threat, depending on the activity and the area.

In addition to typical military and collective defence tasks, the organization has much broader responsibilities. Article 8.1 of the CSTO Charter states that one of the tasks of cooperation between member states is combating international terrorism and extremism, illegal transfer of drugs, psychotropic substances and arms, organized crime, illegal migration and other threats to the security of member states (Charter of the Collective Security Treaty Organization, 2002). It is also worth noting that the threat of external aggression, included in the aforementioned Art. 4 of the CSTO Charter was expanded in the new CSTO Security Strategy until 2025, adopted in October 2016. According to its provisions, the organization must also fight color revolutions and be able to face hybrid wars (Strategiya kollektivnoy bezopasnosti Organizatsii Dogovora, 2016). The CSTO also conducts military operations supporting the police forces, which clearly demonstrates the militarized understanding of security.

\section{Premises for the consolidation of the Member States}

The CSTO is a military alliance of six states out of the twelve that belonged or belong to the Commonwealth of Independent States and the fifteen members of the former USSR. A group of these states is often referred to as pro-Russian, although each of them formally has its own independent foreign and security policy. It is noteworthy, however, that the CSTO holds capabilities regarding the internal affairs of the Member States. They concern situations where extremism, terrorism, and drug and human trafficking are becoming a transnational problem. If the threat creates a need for internal security forces or foreign action, they are left to the exclusive competence of the Member States. This approach is gradually changing, which was reflected in the latest CSTO strategy that provides for measures in the event of riots and serious disorder in a Member State. An example of non-involvement in internal affairs was the ethnic riots between 
Kyrgyz and Uzbeks in southern Kyrgyzstan in June 2010, when the Kyrgyz government asked Russia and the CSTO to help pacify unrest and clashes. However, such help was refused. Officially, the possibility of intervention and interference in the internal affairs of a Member State was rejected by the President Dmitry Medvedev, and the CSTO Secretary General justified the refusal by lack of relevant legal regulations (Weitz, 2015, p. 4). It can be assumed that the reality was completely different. Such intervention would probably be protested against by Uzbekistan, who was then a member of the organization. Conclusions were drawn from this situation, and as early as December 2010 an amendment was introduced to the CSTO charter, obliging Member States to undertake projects to enable the functioning within the organization of the emergency response system, taking care of security, stability, territorial integrity and sovereignty of the Member States (Charter of the Collective Security Treaty Organization, 2002).

One of the values on which the CSTO is based is to respect the sovereignty of states. Its security tasks cover three areas - external, internal and interstate in the context of internal social unrests. This last aspect is the result of leaders - most often authoritarian - in the post-Soviet states being concerned with the possibility of losing power. There have been several cases that may justify this fear. Russia and other countries were worried about the color revolutions in Georgia, Ukraine and Kyrgyzstan - member states of the CSTO. In May 2005, mass protests against the power of President Karimov in Andijan resulted in a brutal intervention by police forces, de facto a massacre in which several hundred people were killed. The United States, present on the territory of Uzbekistan in connection with the ISAF mission, strongly criticized the intervention, threatening to take action with far-reaching consequences. Fearing US interference in Uzbekistan internal affairs, and in fact American forces, Karimov expelled a group of US soldiers stationed at the airport in Khanabad and accused the US of supporting protesters against the legal government of Uzbekistan (Weinstein, 2007).

In 2006 in Belarus, when it was announced that Lukashenko was elected for another term with $83 \%$ support, a wave of protests swept through the country, mainly through Minsk. The protests, brutally suppressed by police forces, were supported by the US government, which believed that the election was rigged. The protesters received severe sentences and as a result, the West imposed sanctions on Belarus. Still, Lukashenko tried to rebuild good relations with the West and his neighbours; he partly succeeded. As in the case of Uzbekistan, the CSTO did not react. 
The Arab spring in 2011 also contributed to the consolidation of organizations around Russia. The US-supported overthrow of regimes in the Middle East revived the memory of colourful revolutions in the post-Soviet space. The leaders of the CSTO member states had to assume that events in the Middle East could be an inspiring example for the opposition. In this situation, greater integration within the organization and the approval of Russian leadership as a real force capable of countering "color threats" has become necessary (Weinstein, 2007).

External threats arising from Western foreign policy are a matter of concern for the CSTO member states. However, it seems that these threats are not related to any act of aggression, but the consequences of promoting Western values and supporting civil society organizations in the CSTO countries. What poses a greater threat to Member States are conflict situations in the post-Soviet states.

The CSTO was encouraged to develop organizational and command structures through the lessons from the wars in Chechnya and Tajikistan and the Azeri-Armenian conflict around Nagorno-Karabakh. Paradoxically, American intervention in Afghanistan negatively affected the cohesion of this political and military alliance. Some states raised concerns about their sovereignty, while others took advantage of the presence of US troops in the region to establish closer relations with the US, supporting the ISAF military operation. Uzbekistan shared its military base in Khanabad and Kyrgyzstan in Manas. As already mentioned, CSTO member states were more concerned with crime and crossborder threats, than with the threat from the West, distant from their borders (Weinstein, 2007).

The process of consolidation of the Member States is also strengthened by joint actions. The operation "Kanal" implemented since 2003 is directed against drug trafficking. The anti-terrorist operation "Border" has been run since 2004 . Representatives of the United Nations, Interpol and selected countries - Bolivia, China, Colombia, Iran, Pakistan, Poland and the US - are invited to observe the exercises. (Nikitina, 2013, p. 3). Operation "Nelegal" (Illegal) is aimed at stopping illegal emigration from countries outside the CSTO, and the operation "Proxy" aims to neutralize extremist websites and coordinate activities in the field of ICT security (Nikitina, 2013, p. 3). Closer cooperation is facilitated by the cyclic comprehensive exercise "Rubezh", which has been conducted regularly since 2004. They include the Joint Staff of the CSTO, units of the Collective Rapid Reaction Forces, representatives of the ministries of the interior, ministries for emergency situations, intelligence and counterintelligence services, military and civilian (Minkina, 2012, p. 51). 
The organization also plays the main role in the annual exercise "Zapad", which is met with sharp criticism of Western media, emphasizing the size of this exercise in terms of personnel involvement and military equipment (Boulègue, 2017). Although in the scenario of these exercises, NATO is always an opponent, the analysis conducted by the author shows that the real scale of Russian involvement is significantly exaggerated. Russia is intentionally overestimating its participation and one may get the impression that the threat arising from these exercises is shaped by the Russian General Staff. The exercise is conducted as part of the military cooperation of the Union State of Russia and Belarus, founded in 1996. On the other hand, it is worth noting that the CSTO focuses on three operational and strategic directions: Eastern European, which is based on Russian-Belarusian military cooperation; South Caucasian with an allied contribution from Armenia; and Central Asia, where the Rapid Reaction Collective Forces stationed at the Kant base in Kyrgyzstan play a key role.

\section{Conclusions}

Russia is the leading, strongest state in the regional security system, and no CSTO country challenges this role. Russia needs the CSTO to strengthen the effectiveness of its foreign and security policy. Undoubtedly, the organization is part of Russia's hegemonic aspirations and its geopolitical interests in the so-called "near abroad". In addition, Russia is still afraid of the possibility that Western influence will expand eastwards, which means gaining political and economic power in regions rich in gas and oil resources. Consolidation within the CSTO is intended to limit this risk. In addition, the CSTO is needed to fight transnational crimes in the area where collaboration with the Shanghai Cooperation Organization takes place (Haas, 2017, pp. 1-16).

At the same time, it should be noted that Russia is seen by the allied states as a reliable partner, bringing measurable military and economic benefits. Member States may benefit from favourable prices for the purchase of armament and military equipment, training and military advice, not to mention the support of the military power of the Russian Federation. In addition, Russia is a guarantee of defence against external and internal threats and against a potential conflict between CSTO countries. Russia is a key country ensuring security and political stability in the Eurasian space.

Thus it can be stated that both Russia and its allies derive certain benefits from membership in the CSTO. However, this does not mean that the Organization 
is free from problems that negatively affect its coherence. In important security matters, Russia is developing enhanced cooperation on a bilateral level with such members of the organizations Armenia and Belarus. It faced a serious challenge after the recent Russian-Ukrainian conflict. Russia has never felt bound by respecting the position of member states when pursuing the interests of its foreign and security policy. The annexation of Crimea was heavily criticized by Belarus and Kazakhstan. Lukashenko did so because of the good relations Minsk enjoys with Ukraine and Georgia. His criticism, however, was relatively moderate and he tried to play the role of a mediator between Russia and Ukraine in the OSCE formula (The Organization for Security and Co-operation in Europe). The leader of Kazakhstan, Nazarbayev, did not approve of the Kremlin's right to protect the Russian minority living outside the borders of the Russian Federation, in the neighbouring countries. He perceived Moscow's decision as a threat to the territorial integrity of Kazakhstan, due to the fact that a large Russian population lives in the northern part of his country, bordering Russia. He also considered such an attitude towards the Russian minority as unacceptable to the CSTO countries, in which part of the population is also of Russian origin (see Douhan \& Rusakovich, 2016).

The Kremlin hopes that reintegration processes in the post-Soviet space under its leadership will be a factor holding back various forms of Western expansion. Despite these benefits, it cannot be ignored that Moscow is reluctant to develop a strong integrated political and military organization with combined command and control structures, and prefers to build its military potential. The main motive for this approach is the cost of maintaining the CSTO. Russia covers fifty percent as it has the greatest potential. This differentiation of commitments demotivates other partners to invest in their own defence, counting in this respect on the strongest member of the organization.

\section{REFERENCES}

Baluk, W. (2008). Wspólnota Niepodległych Państw - integracja czy dezintegracja? In W. Baluk (ed.), Polityka zagraniczna i bezpieczeństwa krajów Wspólnoty Niepodległych Państw (pp. 13-19). Wrocław: Arboretum.

Boulègue, M. (2017). Five Things to Know About the Zapad-2017 Military Exercise. Retrieved from https://www.chathamhouse.org/expert/comment/five-things-knowabout-zapad-2017-military-exercise

Charter of the Collective Security Treaty Organization (2002). Retrieved from http:// en.kremlin.ru/supplement/3506 
Czaputowicz, J. (2008). Teorie stosunków międzynarodowych. Krytyka i systematyzacja. Warszawa: Wydawnictwo Naukowe PWN.

Douhan, A. F., \& Rusakovich, A. V. (2016). Collective Security Treaty Organization and Contingency Planning after 2014. Retrieved from https:/www.dcaf.ch/sites/default/ files/publications/documents/CSTO_ContingencyPlanningAfter2014_eng.pdf

Haas, M. de. (2017). Relations of Central Asia with the Shanghai Cooperation Organization and the Collective Security Treaty Organization. The Journal of Slavic Military Studies, 1, 1-16. Retrieved from https://www.tandfonline.com/doi/abs/10.1080/1351 8046.2017.1271642

Kaszuba, M. (2017). W uścisku Moskwy Obszar poradziecki. Warszawa: Oficyna Wydawnicza Rytm.

Kuźniar, R. (2000). Międzynarodowe stosunki polityczne. In E. Haliżak, R. Kuźniar (ed.), Stosunki międzynarodowe - geneza, struktura, dynamika (pp. 119-141). Warszawa: Wydawnictwo Uniwersytetu Warszawskiego.

Lefebvre, S., \& McDermott, R. N. (2008). Russia and the Intelligence Services of Central Asia. International Journal of Intelligence and Counter Intelligence, 2(21), 251-301.

Legucka, A. (2016). Wykorzystywanie quasi-państw w polityce zagranicznej Federacji Rosyjskiej. Rocznik Nauk Społecznych, nr 1, 8(44), 11-29. Retrieved from https:// www.researchgate.net/publication/312312088_Wykorzystanie_quasi-panstw_w_ polityce_zagranicznej_Federacji_Rosyjskiej

Makarychev, M. (2011, 26 yanvarya). Nenadorugat'spetssluzhby. Gostem „RG” byl ispolnitel'nyy sekretar' SNG Sergey Lebedev, Rossiyskaya gazeta.

Malak, K. (2008). Polityka Bezpieczeństwa Federacji Rosyjskiej na obszarze WNP. In W. Baluk (ed.), Polityka zagraniczna i bezpieczeństwa krajów Wspólnoty Niepodległych Państw (pp. 23-40). Wrocław: Arboretum.

Minkina, M. (2012). Wywiad Federacji Rosyjskiej. Siedlce: Wydawnictwo Uniwersytetu Przyrodniczo-Humanistycznego.

Mowchan, J. A. (2009). The militarization of The Collective Security Treaty Organization, Center for Strategic Leadership - U.S. Army War College, 6-09, 1-6.

Nikitina, Y. (2013) Security cooperation in the Post-Soviet area within the Collective Security Treaty Organization. ISPI - Analysis, 152, 1-5. Retrieved from https://www. ispionline.it/it/documents/Analysis_152_2013.pdf

Strategiya kollektivnoy bezopasnosti Organizatsii Dogovora o kollektivnoy bezopasnosti na period do 2025 goda (2016). Retrieved from http://odkb-csto.org/documents/detail.php?ELEMENT_ID=8382

Strategiya natsional'noy bezopasnosti Rossiyskoy Federatsii do 2020 goda, Utverzhdena Ukazom Prezidenta Rossiyskoy Federatsii ot 12 maya 2009 g. № 537, http://www. scrf.gov.ru/documents/99.html

Vneshnyaya politika (2009). Spetssluzhby stran SNG soriyentirovany na plotnuyu sovmestnuyu rabotu po prioritetnym napravleniyam - glava SVR, ITAR-TASS, 4 sentyabrya. 
Voyennaya Doktrina Rossiyskoy Federatsii (2010). Retrieved from http://kremlin.ru/ supplement $/ 461$

Weinstein, A. (2007). Russian Phoenix: The Collective Security Treaty Organization. The Whitehead Journal of Diplomacy and International Relations, vol. Winter/Spring, 167-180. Retrieved from https://heinonline.org/HOL/LandingPage?handle=hein. journals/whith $8 \&$ div $=3 \&$ id $=\&$ page $=$

Weitz, R. (2014). The Collective Security Treaty Organization: Past Struggles and Future Prospects. Russian Analytical Digest, 152(2-4). Retrieved from http://www.css.ethz. $\mathrm{ch} /$ content/dam/ethz/special-interest/gess/cis/center-for-securities-studies/pdfs/ RAD-152-2-4.pdf 